\title{
Framing Mass Hysteria Covid-19 dalam Berita Tempo dan Detikx
}

\author{
Khairul Arief Rahman', Hamidah Izzatu Laily ${ }^{2 *}$ \\ 1Universitas Gadjah Mada, Yogyakarta, Indonesia, email: khairularief44@gmail.com \\ 2Universitas Gadjah Mada, Yogyakarta, Indonesia, email: hamidahizzatu@gmail.com \\ *Koresponden Penulis
}

\section{Info Artikel}

Submit: 28 Mei 2020

Accepted: 26 Feb 2021

Publish: 12 Maret 2021

Keywords:

Public Policy; Media, News

Construction; Framing

Kata Kunci:

Kebijakan Publik; Media;

Konstruksi Pemberitaan;

Framing

\section{(cc) EY-SA}

Lisensi: cc-by-sa

\begin{abstract}
Coverage of the Coronavirus or Covid-19 in Indonesia was accompanied by confusion of information which resulted Mass Hysteria. Media criticism is also present as the vanguard of social control, which is not only limited to what and how it appeared, but also critically explores readiness from the political level of government to the social life of the affected community. How two "premium" media, namely Tempo and DetikX, build news construction about Covid-19? Then how do the media frame a topic or issue that has developed after Covid-19? and how is the concentration of the media in reporting on Mass Hysteria that developed after Covid-19 in Indonesia? This study takes news in March 2020, Especially on the main coverage presented by both media. This research uses qualitative research method and Pan and Kosicki's framing analysis model for explore data research. The Result is Tempo Magazine and DetikX generally drawing struggle toward Mass Hysteria and affair caused by Covid-19 on critics of handling policy government level and public with selectively choosing solution frame as shape of struggle.
\end{abstract}

\begin{abstract}
Abstrak
Pemberitaan mengenai Virus Corona atau Covid-19 di Indonesia diiringi dengan kesimpangsiuran informasi yang mengakibatkan Mass Hysteria publik. Kritik media pun hadir sebagai garda depan kontrol sosial, yang tidak hanya terbatas kepada apa dan bagaimana seluk beluk kemunculannya, namun juga secara kritis mengeksplorasi kesiapan dari level politik pemerintahan hingga kehidupan sosial masyarakat yang terdampak. Bagaimana dua media "premium" yaitu Tempo dan DetikX dalam membangun konstruksi pemberitaan mengenai Covid-19? Lalu bagaimana media melakukan pembingkaian terhadap suatu topik atau isu yang berkembang pasca Covid-19? dan bagaimana konsentrasi media dalam memberitakan Mass Hysteria yang berkembang Pasca Covid-19 di Indonesia? Penelitian ini mengambil berita pada bulan Maret 2020, khususnya pada liputan utama yang disajikan kedua media. Metode penelitian ini adalah kualitatif dan menggunakan analisis framing model Pan dan Kosicki untuk membedah data. Kesimpulannya Majalah Tempo dan DetikX secara umum menggambarkan perlawanan terhadap Mass Hysteria dan ketakutan akan covid-19 berupa kritik yang menyasar pada penanganan baik di tingkat pemerintah maupun publik dengan memilih bingkai solusi sebagai bentuk perlawanannya.
\end{abstract}

\section{PENDAHULUAN}

Kebijakan Publik dan Media merupakan dua elemen yang dalam praktiknya saling memberi feedback dalam pemberitaan. Utamanya dalam hal menghadapi kondisi-kondisi 
tertentu, kebijakan publik yang menjadi subjek utama pemberitaan dapat melahirkan kepercayaan. Kebijakan publik dapat menenangkan situasi psikologis-sosial, sementara media bisa menjadi penyalur dan pengawas kebijakan tersebut. Tergantung dari sisi mana media tersebut memandang, apakah cenderung netral, pro ataupun kontra dengan tujuan memberi keputusan yang dianggap terbaik. Berkaitan dengan hal tersebut, berita yang muncul terutama pasca konfirmasi kasus perdana Covid-19 di Indonesia tentu menjadi perhatian banyak pihak. Kebijakan pemerintah, kasus di lapangan dan situasi ekonomipolitik menjadi sajian utama media. Kenyataannya di lapangan situasi berubah dengan sangat cepat dan memaksa beberapa pihak mulai dari pemangku kebijakan tertinggi seperti pemerintah dan aparatur sipil mengambil sikap dengan mengumumkan berbagai kebijakan dan klaim yang pada satu sisi mungkin bertujuan menenangkan masyarakat. Namun tampaknya publik belum merasa aman dengan kebijakan dan klaim pemerintah tersebut. Bahkan masyarakat segera berbondong-bondong membeli kebutuhan pokok sebanyak-banyaknya, karena takut kondisi semakin tidak stabil, harga yang naik, hingga larangan keluar rumah oleh pemerintah. Panic buying terjadi di mana-mana, entah merupakan bagian dari antisipasi atau justru kepanikan irasional yang menjadi salah satu gejala dari kepanikan publik.

Mass hysteria sebetulnya adalah istilah dari ilmu psikologi yang merujuk pada ketakutan publik dari sebuah kelompok ke kelompok lainnya (Selden, 1989). Menurut Bartholomew (2016) idealnya sebuah lembaga resmi mengoordinasikan informasi kepada jurnalis dan membatasi jumlah orang yang berbicara, tujuannya untuk mengurangi misinformasi dan kekacauan yang bisa terjadi. Misinformasi inilah yang dikhawatirkan berkembang menjadi Mass Hysteria. Media massa merupakan elemen penting dalam distribusi informasi sehingga memiliki kekuatan pembentuk opini publik. Dalam situasi krisis atau bencana pandemi virus corona seperti saat ini, tingkat kebutuhan masyarakat akan informasi tentu menjadi semakin tinggi, sehingga posisi media massa dalam mempengaruhi cara pandang pembacanya akan semakin kuat. Melalui pemberitaan dan berbagai liputannya, media massa dapat mempengaruhi cara pandang pembacanya untuk semakin tenang dalam menghadapi bencana atau justru sebaliknya semakin panik dan ketakutan.

Menurut Mursito (2012) berita di media massa terkadang bisa menjadi lebih besar dari pada peristiwa aslinya. Hal ini karena berita adalah hasil konstruksi masing-masing media sebagai sebuah saluran yang tidak bebas, karena media merupakan agen yang mendefinisikan realitas. Perbedaan antara realitas peristiwa dengan realitas berita terjadi karena berita adalah hasil dari konstruksi peristiwa, bukan peristiwa itu sendiri. Terjadi transformasi dari realitas empirik (peristiwa) menjadi realitas simbolik (berita). Sebagai realitas simbolik, maka kapasitas berita untuk memuat fakta-fakta peristiwa akan menjadi terbatas. Meski tetap berlandaskan pada kaidah-kaidah jurnalisme, realitas media tak pernah benar-benar dapat merepresentasikan realitas empirik. Dalam pandangan konstruksionis, berita adalah potret dari arena pertarungan antara berbagai pihak yang berkaitan dengan suatu peristiwa. Sehingga, apa yang kita baca bukan hanya menggambarkan realitas tetapi juga menunjukkan konstruksi realitas yang bersifat subjektif dari media itu sendiri.

Prinsipnya media massa memang merupakan sarana bagi manusia untuk dapat memahami realitas sosial. Sehingga media massa dituntut memiliki kesesuaian antara pemberitaan dan realitasnya di lapangan. Namun tidak sempurnanya media dalam mencapai tuntutan tersebut membuat media kerap dituduh bias dalam mengolah informasi. Padahal pada dasarnya, semua media massa memang memiliki peluang untuk mengandung bias, meski dengan derajat yang berbeda-beda. Derajat bias media menurut 
Widaningsih (2008) dipengaruhi oleh paling tidak tiga hal, yaitu kapasitas dan kualitas pengelola media, kuatnya kepentingan yang sedang bermain dalam realitas sosial, serta tingkat kekritisan masyarakat.

Setiap media massa, khususnya yang ada di Indonesia, memiliki kepentingan yang berbeda-beda, baik dalam hal ekonomi, politik maupun ideologi. Begitu pula yang terjadi dengan media besar sekaliber Majalah Tempo dan DetikX, sehingga keduanya tentu memiliki derajat bias media dan pola konstruksi berita yang tidak sama. Di tengah kondisi pandemi virus corona, kekuatan media yang semakin besar mempengaruhi opini publik, dan adanya kepentingan media massa yang berbeda-beda, maka timbullah pertanyaan penelitian: bagaimana dua media "premium" yaitu Majalah Tempo dan DetikX membangun konstruksi pemberitaan mengenai Covid-19? Bagaimana media melakukan pembingkaian terhadap suatu topik atau isu yang berkembang pasca Covid-19? Bagaimana konsentrasi kritik media dalam memberitakan Mass Hysteria yang berkembang Pasca Covid-19 di Indonesia? Atas dasar pertanyaan penelitian tersebut, tujuan penelitian ini adalah: (1) Menemukan pola konstruksi pemberitaan Covid-19 dalam Majalah Tempo dan DetikX. (2) Mengungkap cara media melakukan pembingkaian terhadap topik yang berkembang pasca Covid-19. (3) Mengetahui konsentrasi kritik media dalam memberitakan Mass Hysteria pasca Covid-19.

\section{Jurnalisme di tengah Mass Hysteria}

Kepanikan publik biasanya merupakan konsekuensi logis dari ketidaksiapan pribadi maupun kelompok. Karena itulah istilah Mass Hysteria hadir sebagai sebuah fenomena yang justru dianggap oleh pemerintah maupun para peneliti sebagai sesuatu yang berlebihan. Faktanya Mass Hysteria ada disebabkan berbagai kondisi yang meliputinya. Misalnya ketika HIV/AIDS muncul di Amerika dan Eropa pada dekade 1980-1990 terdapat banyak stigma bermunculan yang mengakibatkan kepanikan publik dan pengucilan bagi para penderitanya (Kilty dan Bogosavljevic 2019). Di Amerika misalnya penyakit ini oleh politisi Republikan disebut sebagai "God's Judgment". Istilah ini juga bisa ditemui dalam masyarakat kita seperti anak yang terkena HIV/AIDS distigmakan sering melakukan hubungan seksual di luar nikah atau orang yang terkena "adzab" karena perilaku menyimpangnya. Contoh di atas bukan berarti peneliti ingin mengatakan bahwa ini adalah suatu hal yang wajar, akan tetapi ketakutan yang terjadi sebetulnya ada pemicunya. Ironisnya hal tersebut terkadang luput dari pengamatan ilmuwan di bidang sosial-politik maupun komunikasi.

Dalam ranah komunikasi dan media sendiri hal ini menjadi masalah mengingat salah satu ketakutan masyarakat adalah dipicu dari pemberitaan di media massa yang cenderung menyalahkan pihak terkait seperti dokter atau pasien (Kilty dan Bogosavljevic 2019). Sampai hari ini kita bahkan masih merasakan apa yang terjadi di masyarakat akibat ketakutan publik tersebut seperti praktek pengucilan seseorang yang dianggap terindikasi penyakit ataupun keluarganya, atau penyematan istilah dan stigma tertentu pada penderitanya. Hal tersebut lalu terakumulasi pada ketakutan personal, yang lalu ditransmisikan hingga akhirnya terakumulasi ke dalam ketakutan kelompok dan massa. Kecenderungan ini lalu melahirkan sejumlah tindakan reaktif yang justru destruktif diakibatkan oleh ketakutan tersebut. Sifat yang merusak inilah yang lalu membuat kerugian di berbagai sektor yang berkelanjutan. Efek ini kerap kali disebut sebagai efek domino, yaitu efek yang terus terulang dan berkelanjutan sekaligus berhubungan antara satu dengan lainnya. Dalam ranah komunikasi sendiri istilah ini jarang digunakan, namun dapat digunakan untuk melihat efek media saat ini yang juga cenderung berulang dan menciptakan kepanikan di segala lini sebagai akibat 
dari ketakutan publik. Berbagai bentuk pelayanan publik sampai sosial kemasyarakatan akan terkena dampaknya, termasuk di dalamnya media dan komunikasi. Kompleksitas faktor tersebut juga menjadi alasan mengapa terkadang pemicu mass hysteria luput dari perhatian meskipun terdapat fakta atau realita yang menguatkan satu kejadian dengan lainnya dalam satu fenomena ini.

Jurnalis pada situasi tersebut otomatis dihadapkan pada kondisi yang beragam dan mau tidak mau harus mengikuti objek kejadian untuk mendokumentasikannya. Perbedaannya adalah jurnalis hari ini bukan hanya agen perubahan atau pendokumentasi sejarah semata, akan tetapi juga garda depan informasi sekaligus aktivis publik. Tugas ganda ini dilakukan oleh jurnalis sebagai salah satu bentuk adaptasi kondisi dan kombinasi atas praktek sosial yang terjadi seperti realitas dan pemaknaan yang bertumpuk (hyperreality), berita palsu atau informasi yang menyesatkan (hoax), cepat berubahnya situasi-kondisi dan faktor yang terkait dengan keputusan politik yang membawa kerugian bagi masyarakat atau publik. Jurnalis mau tidak mau harus bergerak lebih dalam dan menyentuh segala aspek untuk membaca fenomena, alih-alih mengikuti di setiap kejadiannya.

\section{Pembingkaian terhadap Kebijakan Publik}

Fenomena mass hysteria membawa sorotan media salah satunya ke arah bagaimana kesiapan pemerintah dan publik mengingat keduanya merupakan instrumen penting dalam penanganan. Pemerintah selaku pemangku kebijakan diharapkan membuat keputusan penting dan tepat, sementara publik dirasa perlu untuk melakukan sesuatu untuk menghindari kemungkinan terburuk di lingkungannya. Moral publik dalam kenyataannya memegang peranan mendalam yang berimplikasi pada kecondongan akan kepanikan. Menurut penelitian yang dilakukan oleh Frank Furedi (2016) yang berfokus pada potensi media dalam kaitannya dengan kepanikan moral menyatakan media memang bukanlah satu-satunya "pemain" atas kepanikan moral, akan tetapi ia bisa menjadi "sampul depan" kepanikan. Hal ini didasarkan pada potensi media (utamanya cetak) yang secara terus menerus mempertanyakan nilai, moral di lingkungannya, dan otoritas (Furedi, 2016).

Di sisi lain media massa juga dapat membentuk sikap dan perilaku individu berkaitan dengan kesehatan (Rahmadiana, 2012). Peran media massa terlebih dalam fenomena ini bertautan dengan isu lain seperti kesehatan publik (public health), yang menjadikannya penting untuk dibahas mengingat situasi dan kondisinya yang beragam. Penelitian ini merujuk kepada beberapa riset yang dilakukan oleh peneliti di bidang komunikasi terutama hubungannya dengan pembingkaian kebijakan publik. Namun dalam tinjauan pustaka yang dilakukan dalam penelitian sebelumnya, sedikit yang mengaitkannya dengan fenomena tertentu di bidang kesehatan seperti mass hysteria, kesehatan publik atau moral panic. Tinjauan pustaka yang digunakan sebagai rujukan dalam penelitian ini adalah 1.) Penelitian yang dilakukan Van Hulst dan Yanow (2016) berjudul From Policy "Frames" to "Framing": Theorizing a More Dynamic, Political Approach. Dalam penelitian tersebut yang menjadi rujukan lebih kepada bagaimana pembingkaian bekerja pada setiap kebijakan publik secara luas terutama dalam kaitannya dengan relasi politik. 2.) Penelitian yang dilakukan oleh Frank Furedi berjudul Moral Panic and Reading: Early Elite Anxieties About the Media Effect (Furedi, 2016). Penelitian tersebut memang membahas potensi media dalam hubungannya dengan kepanikan moral, namun tidak membahas media secara keseluruhan mengingat dalam penelitian tersebut tidak merujuk pada wacana atau pembingkaian media. 3.) Bartholomew (2016) berjudul Public health, politics and the stigma of mass 
hysteria: lessons from an outbreak of unusual illness. Tulisan Bartholomew ini menjadi yang paling mendekati dengan apa yang diteliti dalam penelitian ini. Membahas mengenai kebijakan kesehatan publik yang mengumumkan diagnosis pasien ternyata justru memperkuat ketakutan publik dan menjadi perhatian media. Berdasarkan tinjauan pustaka tersebut, penelitian ini akan "menyelip" diantara ketiga penelitian sebelumnya, yaitu memberi perhatian mengenai kesiapan pemerintah dan publik dari kacamata media, dan pembingkaian terkait kebijakan publik pada bidang kesehatan.

Ada tiga dimensi bagaimana sebuah pembingkaian bekerja dalam kebijakan publik menurut Van Hulst dan Yanow (2016). Pertama, pembingkaian sebagai "pekerjaan yang masuk akal". Dalam kebijakan publik, pembingkaian adalah proses membuat seorang individu dengan kebijakannya menjadi relevan berkat konstruksi pemaknaannya. Pembingkaian yang juga melibatkan unsur visual, data, teks, rumor dan sebagainya digunakan serta disesuaikan dengan kognisi situasinya. Lokus yang digunakan ada dua, apakah bermain atau melawan. Kedua, pembingkaian sebagai "pekerjaan untuk menyeleksi, menamai dan mengategorisasi". Penyeleksian yang digunakan dalam pembingkaian kebijakan publik sangat erat kaitannya dengan intersubjektivitas dan konstruksinya mengenai dunia sosio-politik. Menamai dan mengategorisasi secara bersamaan digunakan untuk menjelaskan perbedaanperbedaan antar subjek. Penggunaan kata juga digunakan untuk membedakan satu dengan lainnya, hal yang juga sering kita lihat pada media dalam kontestasi politik. Ketiga, pembingkaian sebagai "pekerjaan untuk menceritakan". Pembingkaian dalam ranah kebijakan publik juga menyertakan cerita yang disajikan secara naratif sebagai bagian dari hubungan media dan kebijakan publik. Ini dikarenakan dalam beberapa hal teks media mengandung semacam tulisan naratif atau prosa ketimbang argumen langsung atau struktur logis. Sehingga membuat kebijakan publik lebih bisa diterima sebagai "aksi" ketimbang sebagai sebuah "rencana". Perlu diketahui bahwa dimensidimensi pembingkaian terhadap kebijakan publik di atas merupakan pengalaman Van Hulst dalam meneliti pembingkaian kebijakan publik di Eropa. Sehingga sangat mungkin pembingkaian kebijakan publik di Indonesia memiliki warnanya sendiri.

Terkait tugas jurnalis, dalam hal ini membawa beban ganda yang dibarengi dengan cepatnya perubahan sosial dan politik yang terjadi selama fenomena mass hysteria publik membawa sejumlah permasalahan baru yang menjadi gambaran media. Berbagai situasi politik dan sosial diliput sebagai akibat dari polarisasi perubahan untuk menghindari kemungkinan terburuk yang terjadi. Konsekuensinya antara kejadian yang begitu cepat dan drastis tersebut juga melahirkan kebiasaan dan cara pandang baru di tengah pandemi. Ukuran yang digunakan otomatis bukan masalah baik atau buruk, melainkan rasional atau tidaknya hal-hal tersebut dilakukan selama pandemi berlangsung. Kepanikan publik sebagai bagian dari mass hysteria misalnya tidak serta merta menjadikan perilaku masyarakat sebagai patokan, melainkan melalui kebijakan publik dan rekomendasi ahli juga ikut menentukan konstruksi sosial yang tengah dibangun.

Pada level inilah konstruksi pemberitaan menunjukkan wajah masyarakat dari level sosial hingga politik, tentang apa yang terjadi beserta kronologi kejadian dan kecemasan yang timbul akibat perubahan tersebut. Bangunan mengenai konstruksi pemberitaan pada awalnya pastilah terjadi dikarenakan adanya realitas yang lalu terbangun dalam konstruksi sosial yang membentuknya. Realitas yang ada dalam masyarakat inilah yang lalu membentuk sejumlah penanda seperti simbol, identitas dan berbagai penanda sosial yang menjadi ciri khas dalam sebuah masyarakat. Berger dan Luckmann (1991) membagi realitas yang membentuk realitas sosial menjadi dua, 
pertama realitas objektif, yaitu realitas yang ada dalam kehidupan manusia. Realitas ini bisa kita temui dalam setiap aktivitas manusia seperti memancing, bertani, bekerja dan kegiatan sehari-hari.

Namun apakah pemberitaan di media merupakan realitas yang sepenuhnya tergambar dalam masyarakat? Jawabannya belum tentu atau justru berbeda. Ini dikarenakan media maupun jurnalisme memiliki sejumlah latar belakang yang melingkupinya, yang pada akhirnya menentukan isi berita sendiri sebagai pusat dari informasi. Jurnalisme adalah sebuah bisnis verifikasi, jangankan berbicara jurnalisme itu sendiri, terkadang pusat dari informasinya juga memiliki kekurangan (Wendratama 2017). Artinya media juga memiliki bias tertentu yang melingkupinya, di mana kemungkinan konstruksi beritanya walaupun mengandung nilai verifikasi dan berusaha meng-cover semua hal pasti memiliki fokus dan lokus yang belum tentu sama. Dalam perspektif kritis pun tidak jarang faktor kepemilikan media juga menjadi salah satu sebab perbedaan antara realitas dengan berita yang disajikan. Bahkan mungkin perspektif Berger dan Luckmann (1991) dalam membangun konstruksi realitas sosial yang tanpa menyertakan media perlu untuk mendapatkan kritik. Ini dikarenakan realitas yang terkonstruksi juga membentuk opini massa yang secara singkat cenderung apriori dan sinis dikarenakan sirkulasi informasi, sesuatu yang hilang dari teori ini (Bungin 2006; Chairani dan Kania 2014; Rubawati dan Airlangga 2018; Sitompul 2014).

Berger dan Luckmann (1991) dalam bukunya memang tidak menyertakan media sebagai salah satu komponen pembentuk realitas sosial secara eksplisit. Akan tetapi keduanya memiliki lokus perbedaan antara realitas dan pengetahuan sebagai dua hal yang berbeda, yang mungkin pada satu sisi bisa menjelaskan mengapa antara konstruksi yang dihadirkan media dan realitas sosial juga terdapat perbedaan. Menurut keduanya pengetahuan dibentuk bukan hanya berdasarkan pengamatan empiris, namun bisa juga dijelaskan yang secara sosial dibentuk berdasarkan realitas. Sedangkan realitas adalah sesuatu yang dialami oleh pelakunya. Dalam bukunya ia mengilustrasikan bahwa apa yang menurut biarawan Tibet nyata, belum tentu nyata bagi pebisnis Amerika. Pengetahuan mengenai kriminalitas juga berbeda dengan pengetahuan para ahli kriminologi (Berger dan Luckmann 1991). Sehingga sangat dimungkinkan apa yang dihadirkan oleh media sebagai "transmisi pengetahuan" juga berbeda kejadian di tempat yang merupakan "realitas". Realitas tersebut lalu dikonstruksi sebagai bagian dari pengetahuan yang bertujuan supaya dapat diterima oleh publik. Menurut Bungin (2006) ada empat tahap bagaimana konstruksi sosial muncul. Pertama, tahap menyiapkan materi konstruksi, yaitu bagaimana media memilih materi berita yang akan disajikan. Tahap ini lebih banyak berbicara tentang bagaimana nantinya media memilih fokus yang sesuai dengan kecenderungan media itu sendiri seperti media yang bersifat kapitalistik, keberpihakan semu pada masyarakat, ataupun kecenderungan umum. Lalu yang kedua ialah tahap sebaran konstruksi, di mana dalam hal ini materi yang akan disebarkan dan disesuaikan dengan tema serta waktu penerbitannya, apakah secara berkala atau hanya beberapa episode yang akan dimuat. Ketiga, tahap pembentukan konstruksi, di mana dalam tahap ini konstruksi media dianggap sama dengan konstruksi sosial yang ada oleh media. Ini dikarenakan disaat yang bersamaan bukan hanya konstruksi realitas yang dibentuk, namun juga konstruksi citra yang juga muncul. Keempat, tahap konfirmasi, yaitu ketika media memberi kesempatan audiens untuk memberikan tanggapan yang bersifat pribadi atau argumentasinya. 


\section{Pembingkaian Realitas}

Salah satu hal yang membuat realitas dan konstruksi berbeda adalah adanya pembingkaian (framing). Erving Goffman (1986) peneliti di bidang sosial yang meletakkan dasar framing menyatakan bahwa kehidupan sosial merupakan sebuah pengorganisasian yang terbentuk dikarenakan batas-batas sosial sebuah bangunan atau rencana. Adanya hal tersebut lalu membentuk bangunan sosial, baik domestik, industrial maupun komersial (Goffman, 1986). Jelasnya bahwa konstruksi bukanlah sesuatu yang netral, akan tetapi ia adalah hasil produksi penafsiran atas realitas. Realitas merupakan sesuatu yang bisa dilihat dan dirasakan, namun konstruksi adalah pembedanya. Media memiliki cara sendiri dalam menafsirkan realitas tersebut. Berita yang dihadirkan merupakan produk matang dari konstruksi yang dibangun dan diproses bukan hanya oleh jurnalis, melainkan juga oleh redaktur, editor, news room dan tidak menutup kemungkinan pemilik media yang menaunginya.

Terdapat banyak studi mengenai peran media dalam kaitannya dengan kepanikan moral, namun kerap kali media juga merupakan sebuah instrumen peringatan lewat pesan-pesannya meskipun tidak berfokus pada ketetapan moral (Furedi, 2016). Artinya media meski pada satu sisi sebetulnya memiliki sejumlah peran yang menentukan di tengah situasi publik yang diliputi ketakutan akibat informasi yang simpang siur. Karena pada dasarnya seperti penjelasan Goffman (1986) yang telah kami sebutkan tadi, bahwa pembingkaian (frame) hadir bukan hanya mendasarkan pada konstruksi sosial apa yang terjadi, melainkan dikarenakan kejadian tersebut dirancang dan dibangun sedemikian rupa. Klarifikasi, pencarian fakta dan investigasi otomatis menjadi salah satu cara jurnalis dalam menghadirkan sejumlah fakta yang nantinya dikonstruksi dan dibingkai dari berbagai problematika pemerintah, dan publik. Dalam fenomena yang terjadi sangat cepat dan drastis tersebut, jurnalis di lapangan dituntut bukan hanya cepat menulis tentang apa yang terjadi, tetapi juga klarifikasi dan sikap jurnalis yang diharapkan menjadi "pencerahan" di tengah fenomena mass hysteria. Setiap keputusan yang berpengaruh bagi publik dan ketakutan publik itu sendiri merupakan realitas yang bukan hanya diceritakan, namun dikonstruksi dengan tujuan tertentu. Analisis framing merupakan cara yang tepat untuk menganalisis bagaimana bangunan sebuah berita dibingkai dan menjadi konsentrasi media dalam menghadirkan realitas sosial.

Menurut Pan dan Kosicki (1993) analisis framing adalah pendekatan analisis konstruktivis yang menelaah wacana secara empiris yang bertujuan membuktikan adanya pembingkaian dalam setiap isu. Dalam menjelaskan bagaimana pembingkaian sebuah isu yang ada dalam berita, keduanya membedakan antara apa yang disebut sebagai "bingkai" dan "pembingkaian". Bingkai yang dimaksud oleh keduanya adalah ide, label atau seleksi persepsi. Sedangkan "pembingkaian" adalah memproses bingkai tersebut dengan melibatkan penalaran atau proses kognitif yang biasanya terekam dalam skema dan naskah berita. Konsep ini sebetulnya diambil dari bagaimana pemikiran Goffman (1986) yang juga cenderung membedakan keduanya. Dalam beberapa hal konsep ini juga dipengaruhi oleh Van Dijk (1988) utamanya dalam memahami bahwa suatu struktur teks memiliki kaitan dengan psikologis penulisnya, sehingga pendekatan ini juga menekankan faktor kognisi dalam proses perancangan isu dalam sebuah berita atau sering disebut dengan istilah kognisi sosial. Pendekatan Pan dan Kosicki (1993) ini sebetulnya lahir dari analisis mengenai kebijakan publik dan perpolitikan di Amerika Serikat. Dalam menilai sebuah berita, secara empiris analisis ini menilai dari empat struktur, yaitu Sintaktik, Tulisan/Naskah, Tematik dan Retorik (Pan dan Kosicki 1993). 
Secara singkat, Pertama, struktur sintaksis adalah susunan berita yang dirancang sedemikian rupa sebagaimana halnya piramida terbalik berupa headline, judul, isi, gambar sampai penutup. Kedua, struktur tulisan atau naskah, yaitu bagaimana realitas diceritakan layaknya sebuah cerita mulai dari awal, klimaks cerita sampai akhir beserta kelengkapan berita $5 \mathrm{~W}+1 \mathrm{H}$. Termasuk di dalamnya karakter atau tokoh yang dijadikan rujukan, gambaran kejadian, sampai emosi ditulis sebagaimana layaknya sebuah drama. Ketiga, struktur tematik, yaitu apa yang menjadi fokus isi berita dan bagaimana jurnalis menggunakan setiap elemen untuk menghubungkan satu hipotesis dengan hipotesis lainnya. Pemilihan tema, kata dan kalimat menjadi berpengaruh dalam struktur ini agar berita terlihat logis untuk dibaca. Keempat, struktur retoris, yaitu bagaimana jurnalis menggunakan efek-efek tertentu untuk mendukung hipotesis dan isi keseluruhan berita, seperti pemilihan gambaran, unsur visual, contoh dan metafora (Pan dan Kosicki, 1993).

\section{METODE}

Penelitian ini menggunakan tipe penelitian kualitatif deskriptif berdasarkan pendekatan analisis framing. Analisis framing adalah salah satu model analisis yang bisa mengungkapkan rahasia di balik perbedaan, bahkan pertentangan media dalam mengungkapkan fakta yang penting bagi publik. Subjek yang diteliti adalah konstruksi realitas yang dilakukan oleh dua media, yakni Majalah Tempo dan DetikX. Objek penelitiannya adalah pemberitaan mengenai virus corona, di Majalah Tempo dan DetikX selama bulan Maret 2020. Sumber data primer dalam penelitian ini adalah pemberitaan mengenai virus corona pada halaman utama Majalah Tempo dan DetikX. Terdapat 4 artikel pada halaman utama Majalah Tempo dan 10 artikel DetikX yang juga pada halaman utamanya pada kurun waktu tersebut. Pengumpulan dan analisis data untuk kepentingan analisis framing dilakukan secara langsung dengan mengidentifikasi wacana berita berdasarkan model Zhongdang Pan dan Gerald M. Kosicki. Data hasil identifikasi tersebut dianalisis untuk melihat struktur sintaksis, skrip, tematik, dan retoris.

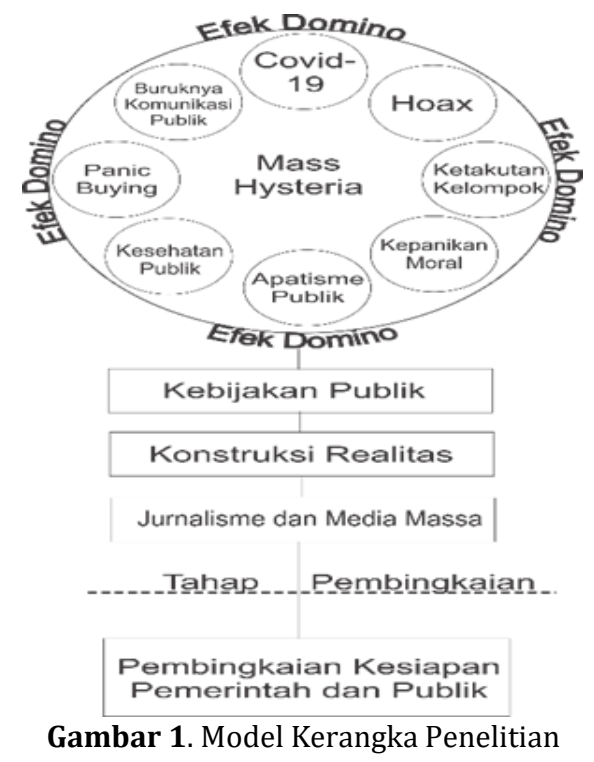

\section{HASIL DAN PEMBAHASAN}

\section{Framing pada Berita DetikX}

Berita pertama berjudul "Memburu (Penimbun) Masker" (7 Maret 2020), ditemukan bahwa jurnalis memulai pembahasan mengenai kelangkaan masker yang 
terjadi akibat panic buying yang terjadi selama Mass Hysteria. Judul ditulis dengan singkat dengan kata "Penimbun" yang terkesan khusus dikarenakan penggunaan tanda petik. Sedangkan yang menarik justru di bagian lead berita yang mengutip seorang pedagang masker "Saya lihat sendiri itu orang Korea beli di sini dibikin bonnya Rp 500 ribu per boks, padahal saya cuma jual Rp 320 ribu.". Menunjukkan bahwa framingnya mengindikasikan penonjolan keadaan pasar yang tidak normal, menandakan adanya hubungan antara penimbunan dan keculasan pasar. Sedangkan pada bagian isi, ditemukan bahwa jurnalis menekankan bukan hanya kelangkaan, melainkan juga dampak penimbunan masker seperti penggelembungan harga dan pendistribusian "gelap". Kesimpulannya adalah konstruksi berita DetikX episode ini adalah secara tematik mengusung kelangkaan masker yang berbasis pada pasar, yang dibingkai mengisyaratkan adanya hubungan pengumuman pemerintah dengan panic buying, penekanan harga dan culasnya permainan pasar yang berdampak pada kenaikan harga masker. Pembingkaian ini bisa dikategorikan pembingkaian relevansi, di mana dalam kebijakan publik pembingkaian semacam ini adalah proses membuat seorang individu dengan kebijakannya menjadi relevan berkat konstruksi pemaknaannya (van Hulst dan Yanow 2016). Ini dibuktikan dengan adanya titik fokus pada berita ini lebih menekankan kepada praktek pasar yang culas dalam pembingkaian dan dihubungkan dengan dampak ketakutan publik.

Berita kedua berjudul DetikX "Virus Corona di Lingkaran Istana" (17 Maret 2020), Pada bagian ini ditemukan bahwa DetikX membahas secara khusus isu penting di lingkungan pemerintahan. Judul yang diusung tidak jauh dengan tema yang diangkat, sedangkan di bagian lead memuat kekhawatiran bahwa virus corona sudah menular di lingkungan istana termasuk presiden sendiri. Mulai dari paragraf keempat sampai kesembilan jurnalis menekankan hal tersebut dengan kejadian awal ketika meninjau Bandara Internasional Jawa Barat di Majalengka pada tanggal 1 Maret 2020 (p.1). Lalu secara berturut-turut jurnalis Rapat Terbatas di Istana pada tanggal 4 Maret 2020 (p.4), dikabarkan sakit tifus pada 10 Maret 2020 (p.4). Rapat terbatas di Istana mengenai permasalahan tanah di Sumatera Utara serta pertemuan dengan Menteri Infrastruktur dan Manajemen Air Belanda pada 11 Maret 2020 (p.7-8), hingga dinyatakan positif Covid-19 pada 14 Maret 2020 (p.11). Kesimpulannya konstruksi yang dibangun DetikX pada berita ini adalah tentang virus corona yang menyebar di kalangan pejabat dengan penekanan bingkai berupa kekhawatiran akan penanganan virus di lingkungan istana. Penekanan pejabat ini otomatis untuk membedakan subjek antara istana dan luar istana. Secara umum pejabat dipandang memiliki akses kesehatan lebih baik dibandingkan masyarakat, sehingga jurnalis cenderung membedakan keduanya sebagai bentuk aktualisasi posisi. Hal ini berbeda dengan pendapat penelitian sebelumnya yang cenderung memandang pengategorian terkait dengan pembedaan intersubjektifitas (van Hulst dan Yanow 2016). Kenyataannya dalam berita ini pengategorian ini lebih spesifik kepada aktualisasi posisi, yaitu bukan membedakan subjek berdasarkan nilai posisi.

Peneliti juga menemukan bahwa terdapat dua berita dengan penekanan yang sama secara berturut-turut. Berita DetikX ketiga berjudul "Adu Cepat Melawan Corona" (18 Maret 2020) dan berita keempat berjudul "Dunia Berburu Vaksin Anticorona" (19 Maret 2020) sama-sama menekankan "perburuan" terhadap virus corona. Perbedaannya adalah pada berita ketiga menekankan masalah penanganan secara kebijakan publik di tingkat nasional, sedangkan pada berita keempat menekankan masalah terkait dengan medis secara menyeluruh di tingkat internasional dan nasional. Berita ketiga lebih kepada kritik DetikX terhadap kebijakan pemerintah sebelumnya 
yang dianggap lamban dalam merespon pandemi Covid-19 yang melanda dunia. Sedangkan pada berita keempat lebih kepada fokus dari tulisan ini adalah keterlibatan publik dalam pengembangan vaksin virus corona yang lebih ditonjolkan untuk menjawab keraguan publik mengenai ada tidaknya tindak lanjut dari segi biologis.

Selanjutnya terdapat dua berita yang diturunkan DetikX mengenai fenomena baru saat awal Pandemi Covid-19, Work From Home (WFH). Dua berita yang diturunkan yaitu berita kelima berjudul "Work From Home: Jemuran Sudah Diangkat Belum" (21 Maret 2020) dan berita keenam berjudul "Work Form Home: Widya Khawatir PHK, Ayunda Lebih Produktif" (23 Maret 2020). Keduanya secara praktis pada bagian sintaksis membahas mengenai kelebihan dan kekurangan Work From Home di awal Pandemi Covid-19. DetikX dalam hal ini tampak menekankan sisi menarik nan menggelikan pada berita kelima pada bagian lead berita. Sedangkan pada berita keenam lebih kepada bagaimana sistem WFH berjalan dan dibingkai dengan kekhawatiran akan PHK meskipun WFH diberlakukan. Menariknya dua berita tersebut dalam struktur sintaksis ditemukan bahwa narasumbernya diambil dari pekerja perempuan. Singkatnya kedua berita tersebut menekankan konsentrasi pada penggambaran kondisi dan kritik pekerja perempuan terhadap sistem WFH, namun dibingkai positif dengan menonjolkan sejumlah kelebihan WFH di akhir berita (utamanya pada berita keenam). Artinya tulisan ini masih menggunakan pembingkaian relevansi. Namun jika pembingkaian semacam ini dimaknai sebagai proses yang membuat seorang individu dengan kebijakannya menjadi relevan berkat konstruksi pemaknaannya (van Hulst dan Yanow 2016), kali ini lebih kepada konstruksi kritik kebijakan WFH yang lebih ditonjolkan dalam berita dengan menekankan pada objek pekerja perempuan.

Berita DetikX selanjutnya berkisar mengenai kebijakan publik. Dua berita yang diturunkan yaitu berita ketujuh berjudul "Pandemi Virus Corona: Kisah Beratnya Tugas Perawat Pasien Corona" (24 Maret 2020) dan berita kedelapan berjudul "Galau Lockdown Istana" (28 Maret 2020). Berita ketujuh meskipun menceritakan kisah perjuangan petugas medis di garis depan penanganan Covid-19, namun isi utamanya pada struktur tematis lebih menggambarkan kekhawatiran tenaga medis akan kekurangan alat seperti Alat Pelindung Diri (APD) dan kebijakan pemerintah mengenai intensif bagi tenaga medis. Sedangkan pada berita kedelapan lebih kepada isu kebijakan publik yang cukup banyak diperbincangkan, yaitu kebijakan Lockdown. Dalam struktur tematik ditemukan adanya kritik jurnalis kepada pemerintah yang memiliki kecenderungan menghindari lockdown, sementara beberapa wilayah menerapkannya seperti yang terjadi di daerah Tegal, Jawa Tengah. Kesimpulannya kedua berita tersebut sama-sama dibingkai dengan mempertanyakan dan mengkritik langkah pemerintah baik mengenai ketidakpastian nasib tenaga medis maupun kebijakan lockdown yang cenderung dihindari oleh pengambil kebijakan di dalam istana. Bingkai kritik semcam ini tidak didapati pada penelitian Van Hulst dan Yanow (2016).

Berita kesembilan dan kesepuluh juga memiliki kesamaan secara tematik, yaitu sama-sama mengangkat masalah ekonomi dan kebutuhan pokok masyarakat ketika awal pandemi Covid-19 berlangsung. Berita kesembilan berjudul "Orang Biasa Pintar Hadapi Corona" (29 Maret 2020) yang penekanannya lebih kepada perputaran ekonomi yang berkutat pada pedagang sayur sebagai objeknya. Judul berita yang sekilas mirip dengan tagline salah satu iklan obat masuk angin tersebut dimaksudkan agar proses adaptasi sebagai bahan untuk bercerita. Berjualan sayur dengan cara online lalu cara pemesanan, pengantaran dan lain sebagainya merupakan cerita 
dominan yang ada dalam isi artikel ini. Sedangkan berita kesepuluh berjudul "Thanos Snap 'Penakluk' Corona” lebih berfokus seputar bisnis makanan dan minuman selama pandemi dan dicampur dengan topik kemanusiaan sebagai bingkainya. Kedua berita tersebut sama-sama mengadopsi penggunaan bahasa yang sama seperti sebelumnya, yaitu bercerita kegiatan bisnis menggunakan cerita personal. Intinya kedua artikel ini berfokus pada kondisi dan kebutuhan publik, yang mungkin terlewatkan selama Mass Hysteria Covid-19. Berbeda dengan berita sebelumnya, kedua berita ini mengusung pembingkaian bersifat naratif. Pembingkaian dalam ranah kebijakan publik juga menyertakan cerita yang disajikan secara naratif sebagai bagian dari hubungan (van Hulst dan Yanow 2016). Namun dalam berita ini cerita naratif tersebut dibingkai dengan penekanan solusi, yang menjadikannya masuk akal untuk dibaca.

\section{Framing pada Majalah Tempo}

Berita pertama pada Majalah Tempo berjudul "Lobi Corona di Jenewa" (Majalah Tempo edisi 'Tergagap Corona', 7 Maret 2020). Jika dianalisis berdasarkan struktur sintaksisnya, maka headline yang diusung menyoroti banyaknya pihak yang mempertanyakan keterbukaan informasi dari pemerintah dalam menghadapi krisis corona, hingga Menteri Luar Negeri yang melobi Badan Kesehatan Dunia (WHO). Menariknya adalah jurnalis mengungkap di bagian akhir, bahwa internal pemerintah sendiri ternyata dirundung keraguan, yakni Presiden yang ragu dengan Menteri Kesehatannya. Kesimpulan dari laporan utama Majalah Tempo ini secara umum membahas mengenai buruknya komunikasi pemerintah dalam penanganan corona di Indonesia, ditambah dengan informasi mengenai keraguan dari dalam dan luar negeri mengenai kemampuan pemerintah menangani corona. Ditutup dengan upaya Menteri Luar Negeri berkonsultasi dengan WHO mengenai kondisi di Indonesia. Apabila ditelaah menggunakan dimensi pembingkaian berita dalam kebijakan publik menurut Van Hulst \& Yanow (2016) pembingkaian dalam berita ini termasuk dalam jenis pembingkaian relevansi, yang salah satunya melibatkan unsur rumor untuk disesuaikan dengan kognisi situasi pandemi yang sedang terjadi. Lokus yang digunakan dalam pemberitaan ini adalah melawan, terlihat dari caranya menjabarkan kelemahan pemerintah dalam penanganan virus corona di Indonesia.

Berita kedua Majalah Tempo berjudul "Menyangkal Krisis Menuai Bencana" (Majalah Tempo edisi 'Compang Camping Corona', 14 Maret 2020). Jurnalis membahas mengenai salah langkah yang diambil Presiden Joko Widodo dalam menghadapi virus Corona. Headline yang diungkap dalam laporan ini adalah kekisruhan dalam pengadaan alat pendeteksi corona dan dugaan monopoli pengujian virus. Bagian lead diisi dengan informasi mengenai WHO yang mempertanyakan lagi keterbukaan pemerintah dalam mengatasi virus corona. Kritik dari berbagai pihak ini semakin gencar setelah Presiden mengakui bahwa pemerintah tidak membuka semua data penyebaran virus corona pada publik. Bahkan presiden juga menolak penggunaan istilah 'krisis' dalam menghadapi corona. Kesimpulannya, upaya pemerintah untuk menutupi data penyebaran virus corona dan menolak penggunaan kata krisis agar masyarakat tidak panik, justru menuai permasalahan-permasalahan baru dan kerepotan pada rumah sakit-rumah sakit yang seharusnya tidak perlu terjadi.

Berita ketiga berjudul "Akrobat Tanpa Kabar Pusat" (Majalah Tempo edisi 'Compang Camping Corona', 14 Maret 2020). Apabila dilihat dari struktur sintaksisnya, jurnalis mengangkat topik utama mengenai koordinasi antara pemerintah pusat dan daerah yang tidak sejalan dalam penanganan corona. Lead berita ini membahas mengenai Grup Whatsapp yang dibentuk Kementerian Kesehatan berisi kepala dinas 
kesehatan dari berbagai daerah di Indonesia. Wartawan menulis keadaan tersebut pada bagian lead untuk menggambarkan bahwa akhirnya ada tanda-tanda jalan keluar dari masalah komunikasi yang kurang terbuka antara dua pihak tersebut. Setelah banyaknya korban berjatuhan di daerah akibat terlambat penanganan karena pusat yang terus saja irit membagikan data penderita corona padahal keadaan semakin memburuk. Di bagian isi membahas tentang pemerintah daerah yang mulai berinisiatif mengambil langkah mandiri untuk menanggulangi penyebaran wabah. Kesimpulannya bahwa konstruksi berita Majalah Tempo ini mencoba untuk meredam kepanikan publik, namun tanpa menutup-nutupi permasalahan yang ada yakni buruknya komunikasi pusat dan daerah. Sementara titik fokus pada berita ini adalah daerah merasa dirugikan atas sikap pusat yang tidak terbuka, sehingga mereka mengambil langkah mandiri tanpa koordinasi dengan pusat. Hal tersebut ternyata memantik kritik dari pusat yang mulai gusar akan langkah-langkah di daerah dan barulah akhirnya lahir sebuah solusi. Pembingkaian yang digunakan dalam berita ini berdasarkan Van Hulst \& Yanow (2016) adalah jenis pembingkaian story-telling atau pembingkaian yang bertugas untuk menceritakan sesuatu, dalam hal ini menceritakan bagaimana komunikasi di pemerintahan untuk menangani corona.

Berita keempat berjudul "Garda Depan Minus Senjata” (Majalah Tempo edisi 'Darurat Covid-19', 21 Maret 2020). Dikaji dari struktur sintaksisnya menunjukkan bahwa jurnalis mengangkat headline tentang tenaga medis yang minim peralatan dan perkiraan para ahli bahwa kasus positif corona di Indonesia akan melonjak. Lead berita ini ditulis jurnalis dengan gaya bercerita, mengisahkan seorang perawat di RSPI Sulianti Saroso yang harus berhemat dalam menggunakan alat pelindung diri karena stok menipis dan pasien yang semakin banyak. Pada bagian isi, jurnalis memaparkan data-data dari para ahli mengenai perkiraan jumlah orang yang akan terjangkit virus corona. Selain itu, dipaparkan pula prediksi bahwa jumlah ruang isolasi, ventilator, dan tenaga medis tidak akan mampu menangani lonjakan jumlah pasien corona. Di akhir, jurnalis menuliskan klaim-klaim pemerintah yang menyatakan Indonesia siap dan mampu mengatasi pandemi ini. Singkatnya, konstruksi berita yang diangkat yakni tentang prediksi melonjaknya pasien positif corona yang tidak dibarengi dengan kesiapan rumah sakit di Indonesia menanganinya. Berita ini juga didominasi nada khawatir akan minimnya peralatan yang dimiliki rumah sakit, namun menutupnya dengan rencana yang telah dibuat pemerintah, untuk sedikit memberikan angin segar dan optimisme pada publik. Berita ini masuk dalam dimensi pembingkaian kebijakan publik yang pertama menurut Van Hulst \& Yanow (2016), sebab pembingkaian ini melibatkan unsur data-data yang disesuaikan dengan kondisi saat itu.

\section{Pembingkaian berita DetikX dan Tempo: Komparasi}

DetikX dan Majalah Tempo membangun konstruksi pemberitaan mengenai covid-19 dengan cukup berbeda, karena keduanya tentu memiliki kepentingan ekonomi dan politik yang tidak sama. DetikX dalam pemberitaannya mengenai Covid19 kerap menguak sisi-sisi personal narasumbernya, seperti cara adaptasi pedagang di pasar, pekerja yang harus menjalani sistem Work From Home (WFH), dan cerita harian petugas medis. Meskipun begitu, ada beberapa berita DetikX yang memilih lingkup lebih besar seperti kritik terhadap pemerintah dan mempertanyakan langkah pemerintah yang cenderung menghindari kebijakan lockdown. Pada Majalah Tempo pembahasan terkait pemerintah dan sistem yang dijalankannya mendominasi hampir semua berita. Misalnya, Tempo mengkritik buruknya komunikasi pemerintah pusat 
dengan pemerintah daerah dalam menangani corona, dan kritik terhadap langkah pemerintah menutupi data penyebaran corona.

Dalam mengemas lead berita, keduanya juga berbeda. DetikX lebih sering menggunakan kutipan langsung daripada Majalah Tempo. Kesamaan dua media ini dalam konstruksi berita adalah, baik Majalah Tempo maupun DetikX sama-sama berupaya menginformasikan solusi maupun rencana solusi dari permasalahan saat ini jika memang ada. Dibalik kritik, kekhawatiran, dan informasi mengenai kondisi buruk yang disebabkan pandemi corona, kedua media ini tetap berusaha meredam kepanikan publik. Misalnya, detikX memaparkan solusi yang diambil pemerintah dalam mengatasi praktik penimbunan masker dan upaya vaksin dalam negeri agar publik tidak khawatir. Pada Majalah Tempo, informasi bernada solusi itu tampak pada langkah yang diambil pemerintah pusat membuat grup Whatsapp dengan Dinas Kesehatan daerah agar komunikasi dari atas ke bawah semakin lancar. Selain itu, juga rencana pemerintah membangun rumah sakit dan menambah peralatan medis sebagai solusi dari prediksi membludaknya pasien corona.

Dalam penelitian yang dilakukan Van Hulst dan Yanow (2016) ditemukan bahwa ada tiga dimensi bagaimana sebuah pembingkaian bekerja dalam kebijakan publik, yaitu konstruksi pemaknaan, pengategorian dan cara bercerita (van Hulst \& Yanow, 2016). Jika pola tersebut digunakan pada penelitian ini, maka terlihat bahwa posisi Majalah Tempo dan DetikX dalam membingkai beritanya cenderung mencampur ketiga pola tersebut namun dengan nuansa kritik. Artinya kedua media tersebut tidak hanya melakukan bagaimana bingkai bekerja, melainkan juga bagaimana bingkai dapat digunakan sebagai perlawanan. Dalam artikel investigasi, media cenderung menyajikan informasi secara lebih mendalam, baik dengan melibatkan unsur visual, data, teks, dan yang lain. Kedua media tersebut melakukan hal tersebut meskipun terdapat perbedaan dari kedua media, yaitu cara penyajian informasinya, Tempo lebih banyak menggunakan data-data ilmiah baik ditulis dalam teks maupun disajikan dalam bentuk infografis. Sementara DetikX menggali informasi secara mendalam dari sisi yang terdampak misalnya pelaku usaha, konsumen, hingga karyawan perusahaan. DetikX juga menjadikan pernyataan pihak-pihak tersebut sebagai kutipan langsung, untuk memperkuat berita. Artinya jika Frank Furedi (2016) yang berpendapat bahwa media memiliki potensi sebagai "sampul depan" kepanikan, maka dalam penelitian ini bisa dikatakan setidaknya ada usaha media untuk meredam kepanikan dengan pembingkaian solutif. Hal ini sejalan dengan upaya untuk meredam informasi yang tidak perlu dan misinformasi yang berakibat pada kebingungan publik (Bartholomew 2016).

Apabila merujuk pada empat tahapan munculnya konstruksi sosial sebagaimana pendapat Bungin (2006) maka pada tahap pertama yakni menyiapkan materi konstruksi, kedua media yang diteliti ini memiliki fokus berbeda dalam memilih berita. Tempo lebih fokus pada berita-berita terkait kebijakan pemerintah dan ruang lingkupnya nasional, bahkan ketika menginformasikan kejadian di daerah saja, Tempo akan selalu membawanya pada level makro dan mengaitkannya dengan kebijakan di pusat. Sedangkan DetikX lebih beragam dalam menentukan fokus yang dipilih, ada berita mengenai kebijakan pemerintah pusat hingga berita tentang kehidupan seharihari pedagang.

Selanjutnya, pada tahapan kedua yakni tahap sebaran konstruksi, kedua media ini juga berbeda. Majalah Tempo adalah majalah berita mingguan yang diterbitkan oleh Tempo Media Group, sehingga sebagai media yang terbit satu minggu sekali, Tempo lebih leluasa memilih topik yang paling menarik dalam satu minggu kebelakang dan 
leluasa mengumpulkan data. Sedangkan, DetikX adalah salah satu platform dalam naungan yang sama dengan Detikcom, terbit setiap hari namun mengkhususkan diri pada laporan investigasi. Sehingga meski mencoba melaporkan informasi secara mendalam, waktu yang dimiliki DetikX cenderung lebih terbatas daripada Tempo.

Ketiga, pada tahap pembentukan konstruksi, kedua media cenderung membentuk konstruksi realitas bahwa setiap kepanikan di masyarakat akan menemui solusinya, cepat atau lambat. Membutuhkan waktu dan proses bagi masyarakat maupun pemerintah selaku pemangku kebijakan dalam menyesuaikan diri dengan keadaan pandemi covid-19 ini. Optimisme coba dibangun oleh kedua media, di tengah kritik yang juga gencar ditujukan pada pemerintah, bukan pada dokter atau pasien seperti pada penelitian sebelumnya yang dilakukan Kilty dan Bogosavljevic (2019). Dengan begitu media mencoba menghindari kemungkinan terburuk seperti menstigma pasien. Terakhir adalah tahap konfirmasi, pada tahap ini kedua media mempunyai makna yang lebih spesifik, sebagai perbandingan atas ketakutan dan fakta di lapangan berupa adaptasi terhadap kebijakan publik. Konfirmasi dalam hal ini berarti bukan dimaknai sebagai tanggapan, melainkan menawarkan sebuah "cara" untuk menghadapi perubahan sosial dalam kehidupan politik dan keseharian.

\section{KESIMPULAN}

Laporan investigasi yang dimuat dalam Majalah Tempo dan DetikX secara umum menggambarkan perlawanan terhadap Mass Hysteria dan ketakutan akan covid-19 berupa kritik yang menyasar pada penanganan baik di tingkat pemerintah maupun publik secara personal. Konstruksi pemberitaan yang dibentuk adalah adanya pemilihan bingkai solusi atas ujian pandemi ini, meski tentu membutuhkan proses. Keduanya dalam pemberitaan juga menuliskan solusi-solusi yang sudah ada di lapangan, baik dilakukan secara personal oleh masyarakat maupun berupa kebijakan publik oleh pemerintah. Hal tersebut berimplikasi pada konsentrasi keduanya yang cenderung sama, yaitu mengkritik namun dengan penekanan berbeda dengan mengedepankan data pada Majalah Tempo dan adaptasi personal pada DetikX.

\section{DAFTAR RUJUKAN}

Bartholomew, R. E. (2016). Public health, politics and the stigma of mass hysteria: lessons from an outbreak of unusual illness. Journal of the Royal Society of Medicine, 109(5), 175-179. https://doi.org/10.1177/0141076816628866

Berger, P. L., \& Luckmann, T. (1991). The Social Construction of Reality: A Treatise in the Sociology of Knowledge. Penguin Books, 1-125. https://doi.org/10.1163/157006812X634872

Bungin, B. (2006). Sosiologi komunikasi: teori, paradigma dan diskursus teknologi komunikasi di masyarakat. Prenada Media Group.

Chairani, D., \& Kania, D. (2014). KONSTRUKSI REALITAS DALAM PEMBERITAAN PELANTIKAN PRESIDEN JOKO WIDODO Analisis Framing pada Laporan Utama Majalah TEMPO dan Majalah GATRA. Journal Communication Spectrum, 3(2), 121139.

http://journal.bakrie.ac.id/index.php/Journal_Communication_spectrum/article/vi ew/1762

Furedi, F. (2016). Moral Panic and Reading: Early Elite Anxieties About the Media Effect. Cultural Sociology, 10(4), 523-537. https://doi.org/10.1177/1749975515626953

Goffman, E. (1986). Frame Analysis: An Essay on the Organization of Experience. In Northeastern

University

Press

(pp.

1-577). 
https://doi.org/10.1176/ajp.132.10.1093-a

Kilty, J. M., \& Bogosavljevic, K. (2019). Emotional storytelling: Sensational media and the creation of the HIV sexual predator. Crime, Media, Culture, 15(2), 279-299. https://doi.org/10.1177/1741659018773813

Mursito BM. (2012). Realitas Media. Smart Media.

Pan, Z., \& Kosicki, G. M. (1993). Framing Analysis: An Approach to News Discourse. Political and Communication, 10(1), 55-75. https://doi.org/10.1080/10584609.1993.9962963

Rahmadiana, M. (2012). Komunikasi Kesehatan: Sebuah Tinjauan. Jurnal Psikogenesis, 1(1), 88-94. https://doi.org/10.24854/jps.v1i1.38

Rubawati, E. (2018). PAPUA DALAM MEDIA (Analisis Framing Media Lokal Radar Sorong dan Antara Papua Barat Terhadap Pemberitaan Otonomi Khusus di Papua Barat). Jurnal Masyarakata Dan Budaya, 20(3), 375-390. https://doi.org/10.14203/jmb.v20i3.671

Selden, B. S. (1989). Adolescent epidemic hysteria presenting as a mass casualty, toxic exposure incident. Annals of Emergency Medicine, 18(8), 892-895. https://doi.org/10.1016/S0196-0644(89)80221-5

Sitompul, P. (2014). KONSTRUKSI REALITAS PERAN KPK DALAM PEMBERITAAN ONLINE TERKAIT KASUS KORUPSI (Studi Framing Beberapa Pemberitaan Online Terkait Peran KPK pada Kasus Korupsi Mantan Gubernur Banten Ratu Atut Chosiah). Jurnal Studi Komunikasi Dan Media, 28(2), 169-182. https://doi.org/10.31445/jskm.2014.180203

Van Dijk, T. A. (1988). News as Discourse. In Lawrence Erlbaum Associates. https://doi.org/10.1002/9781405186407.wbiecn020

van Hulst, M., \& Yanow, D. (2016). From Policy "Frames" to "Framing." The American Review of Public Administration, 46(1), 92-112. https://doi.org/10.1177/0275074014533142

Wendratama, E. (n.d.). Jurnalisme Online: Panduan Membuat Konten Online yang Berkualitas dan Menarik.

Widaningsih, T. (2008). Konstruksi Realitas Perempuan dalam Berita Harian Kompas. 